\title{
MISE AU POINT D'UNE MÉTHODE QUANTITATIVE D'ÉTUDE DE L'ABSORPTION CHEZ LE PORC
}

\author{
A. RÉRAT \\ avec la collaboration technique de P. VAugelade \\ Station de Recherches sur l'Élevage des Porcs, \\ Centre national de Recherches zootechniques, I. N. R. A., \\ 78 - Jouy-en-Josas
}

Dans la mesure où la veine porte représente la voie principale qu'emprunte la plupart des produits de la digestion après leur résorption par le tube digestif, la variation des concentrations de divers nutriments dans le sang efférent (veine porte) par rapport au sang afférent (artère mésentérique) permet une étude chronologique et qualitative de l'absorption. Si l'on veut en outre connaître les quantités de nutriments mis à la disposition de l'organisme, il devient nécessaire de préciser les variations de débit du sang dans la veine porte. Une étude quantitative de l'absorption nécessite ainsi la mise en cuvre de techniques permettant d'une part d'obtenir simultanément des échantillons de sang porte et de sang périphérique, et d'autre part, de mesurer le débit du sang dans le système porte intestinal.

Il y a déjà un certain temps qu'une technique indolore de prélèvement du sang par canulation permanente de la veine porte a été mise au point chez le Porc (ARSAc et RérAr, I962) ; elle a été améliorée récemment de telle sorte que le sang puisse être analysé de façon continue avec un appareil Technicon, soit en ce qui concerne les sucres (AuMAITRE et al., r969), soit en ce qui concerne l'urée et l'ammoniaque (Rérat et Aumaitre, I97I). Sur le même principe, une technique de canulation permanente de la veine jugulaire qui a été mise au point permet l'obtention indolore, en continu ou en discontinu, d'échantillons de sang jugulaire considéré comme représentatif du sang périphérique.

Il est ainsi possible d'établir à tout moment au niveau du tube digestif les différences artérioveineuses de concentration de divers nutriments.

Par ailleurs, nous avons précisé les modalités d'une technique d'étude permettant de connaître, chez le Porc, le débit sanguin dans la veine porte, ses variations et les facteurs susceptibles d'intervenir (RERAT, I97I). Le principe de la méthode utilisée consiste à créer un champ magnétique de faible intensité, perpendiculairement au courant sanguin, et à mesurer la variation de force électromotrice induite par le déplacement du sang, variation qui est en relation avec la vitesse de ce dernier (KoLIN, I952). Dans ce but, un débitmètre électromagnétique Medicon $\mathrm{K} 2000$ a été utilisé avec des sondes en epoxy, modèle $\mathrm{K}$ (Statham) de $\mathrm{I} 2$ à $\mathrm{I}_{4} \mathrm{~mm}$ de diamètre intérieur, formant des bracelets que l'on peut refermer autour de la veine porte après l'avoir dégagée sur une longueur correspondant à la largeur des sondes.

La mise en œuvre simultanée de ces techniques permet, en tenant compte des variations instantanées de débit et de concentration, d'apprécier qualitativement et quantitativement les produits de la digestion après un repas de composition connue administré en quantité déterminée. Une première application a été réalisée sur l'absorption des glucides ; un exemple en est donné dans le tableau I où sont rapportées les variations de glycémie porte et jugulaire et les variations de débit porte après un repas de $50 \mathrm{~g}$ de cérélose administré à un porc de $35 \mathrm{~kg}$ de poids vif. 


\section{SUMMARY}

\section{QUANTITATIVE METHOD FOR STUDYING THE DIGESTIVE ABSORPTION IN THE PIG}

As the portal vein constitutes the main pathway for the transit of most of the digestive products after their resorption by the digestive tract, the variation in the concentration of various nutrients in the efferent blood (portal vein) in comparison with the afferent blood (mesenteric artery) makes possible a chronological and qualitative study of the absorption. Moreover, in order to know the amounts of nutrients at the disposal of the organism, it is necessary to define more accurately the variations of the blood flow rate in the portal vein. Thus, when realizing a quantitative study of the absorption, it is necessary to use techniques by means of which one may, on the one hand obtain simultaneous samples of portal blood and peripheric blood, and on the other hand measure the blood flow rate in the intestinal portal system.

Some time ago, a painless technique of blood sampling by chronic canulation of the portal vein has been perfected in the pig (ARSAC and RÉRAT, 1962); recently this method has been improved so as to analyse the blood continuously with a Technicon apparatus, either as concerns sugars (Aumattre and al., 1969) or urea and ammonia (RERAt and Aumaitre, I97I). Using the same principle, a technique of permanent canulation of the jugular vein makes possible painless, continuous or discontinuous obtention of samples of the jugular blood considered as representative of the peripheric blood. Thus, at any moment, it is possible to estimate the arteriovenous differences as concerns the concentration of the various nutrients at the level of the digestive tract.

Moreover, we have defined the modalities of a technique used in the pig to study the blood flow rate in the portal vein, its variations and the factors liable to intervene (RÉRAT, 1971). The principle of the method used consists of the creation of a magnetic field of low intensity, perpendicular to the blood flow, and of measuring the variation in the electromotive force induced by the circulation of the blood, variation which is related with the flow rate of the latter (Kolin, 1952). With this object, we used an electromagnetic flowmeter with epoxy flow probes, model $\mathrm{K}$ (Statham), with an internal diameter of $\mathrm{I}_{2}-\mathrm{I}_{4} \mathrm{~mm}$, constituting bracelets which can be put around the portal vein after denudation, the length of which corresponds to the width of the probes.

When using these techniques simultaneously and when taking into account the immediate variations of the flow rate and the concentration, it is possible to estimate, qualitatively and quantitatively, the digestion products after a meal of known composition distributed in determined quantities. This method was first applied to the absorption of glucides; table I gives an example of the variations in portal and jugular glycemia and variations of the portal flow rate after a meal of $50 \mathrm{~g}$ cerelose given to a pig weighing $35 \mathrm{~kg}$.

\section{RÉFÉRENCES BIBLIOGRAPHIQUES}

Arsac M., Rérat A., rg62. Ann. Biol. anim. Bioch. Biophys, 2, 335-343.

Aumaitre A., Février C., Rérat A., Rigaud J., Thivend P., ig69. C. R. Acad. Sci., Paris, 268, $717-720$.

Kolin A., I952. Rev. Sci. Instr., 23, 235-242.

RÉrat A., 1971. Ann. Biol. anim. Bioch, Biophys., 11, 175-180.

Rérat A., Aumaitre A., 197x. Ann. Biol. anim. Bioch. Biophys. 11, 348-349. 


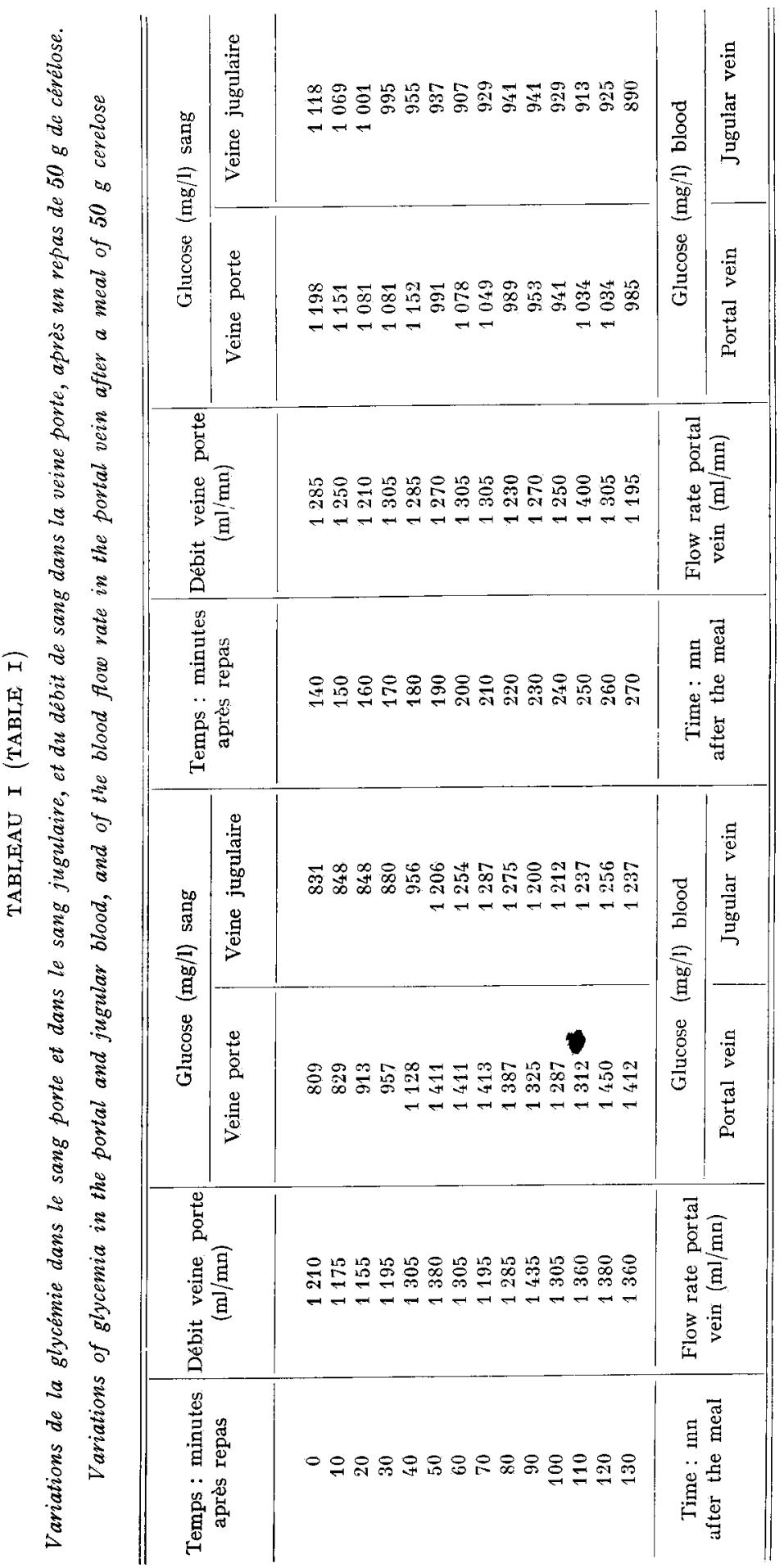

